International Journal of Physical Sciences and Engineering
Available online at http://sciencescholar.us/journal/index.php/ijpse
Vol. 3 No. 2, August 2019, pages: $34 \sim 43$
e-ISSN : 2550-6943, p-ISSN : 2550-6951
https://doi.org/10.29332/ijpse.v3n2.330

\title{
Photovoltaic System Proposal for a House
}

CrossMark

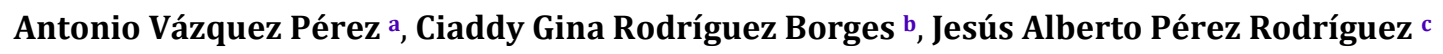

Article history: Received 18 December 2018, Accepted: 30 April 2019, Published: 30 August 2019

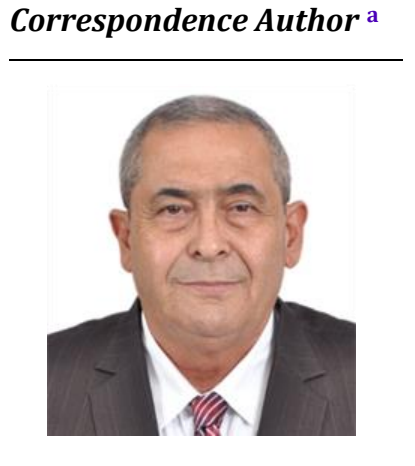

Keywords

distributed generation; emissions; environmental impacts; photovoltaic systems; solar energy;

\begin{abstract}
This work shows the design project of a photovoltaic system to power a home, based on a demand study and its general characteristics, the area available for the assembly was considered of the modules, the geographical location and the meteorological data of the place. With this information, the pertinent calculations were made to ensure that the installation provides the energy necessary to cover the consumption of the home and that it also delivers the surplus energy to the network. PVsyst software was used for the design of the photovoltaic system. To verify the advantages of the implementation of the photovoltaic arrangement, the benefit-cost ratio was evaluated, carrying out an environmental impact analysis taking into account the reduction of $\mathrm{CO} 2$ emissions into the atmosphere and the tons of fossil fuel stopped burning when generating electricity with This source of energy. It is convenient to install.
\end{abstract}

e-ISSN: 2550-6943, p-ISSN: 2550-6951 ๑Copyright 2019. The Author. SS Journals Published by Universidad Técnica de Manabí. This is an open-access article under the CC BY-SA 4.0 license (https://creativecommons.org/licenses/by-sa/4.0/) All rights reserved.

\section{Contents}

Abstract

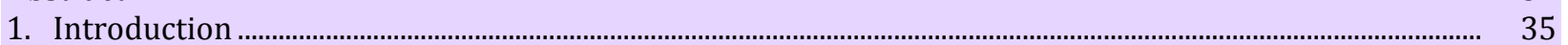

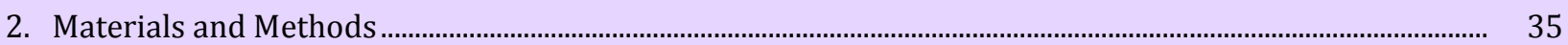

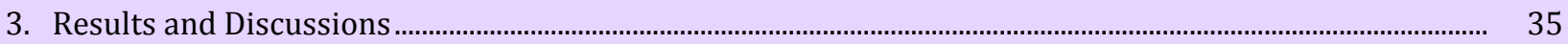

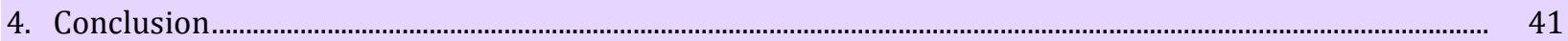

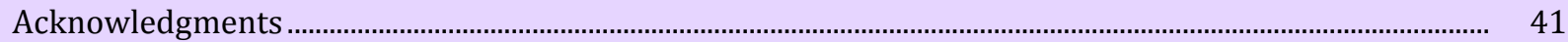

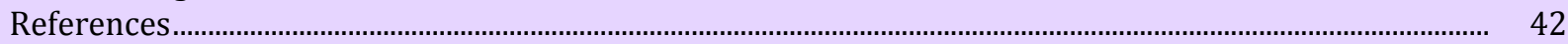

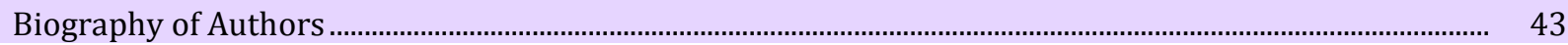

a Universidad Técnica de Manabí, Portoviejo, Ecuador

b Universidad Técnica de Manabí, Portoviejo, Ecuador

c Universidad Técnica de Manabí, Portoviejo, Ecuador 


\section{Introduction}

The increase in the excessive dependence on fossil fuels to obtain electricity has caused the depletion of their reserves and severe damage to the environment, as a result of the emissions of harmful gases that occur with the burning of coal, oil and gas natural, effects that are elements that accelerate in climate change, being a threat to the human species. Betting on the use of renewable energy sources (FRE), nowadays as an alternative allows to solve the immediate need of man by being able to replace fossil fuels and provide a service with better quality and achieve the energy sustainability of the housing (Rodríguez et al., 2018).

The sun is the source that brings all the energy to the earth. The incidence of its radiation allows the processes of photosynthesis, transforming the energy of solar rays into chemical energy, essential for plant and animal life. The photosynthetic process has allowed the formation of fossil fuels. The sun is in the genesis of the winds and is the engine that moves the hydrological cycles.

Directly, solar energy appears in the form of solar energy itself, hydraulic or wind energy. The solar energy received on the earth's surface has been calculated and is approximately equivalent to 178,000 TW-years (Beltrán-Telles et al., 2017). In 1990 it was estimated that this amount was 15,000 times higher than global consumption. However, about $30 \%$ of this energy is reflected in space, $50 \%$ is absorbed, converted into heat and forwarded to the earth's surface; of this 50\%, 49,000 TW-years are forwarded as heat energy in the form of electromagnetic radiation and 40,000 TW-years (CIE, 2008) as caloric energy itself.

The remaining $20 \%$ allow the formation of winds $(\sim 350 \mathrm{TW})$, power the hydrological cycles $(\sim 35,000$ TW) and only a very small part of the solar energy is used by photosynthesis, thanks to which the planetary biodiversity exists (100 TW).

Geothermal energy, also considered renewable and coming from the process of cosmic formation, can be subtracted from the earth's crust to a value of 30 TW year. The energy of the tides, created by the attraction of the Moon, can also deliver a small part of the usable energy of the order of 3 TW-years. Estimates of the potential of renewable energies (primary biomass, solar energy, hydraulic energy, wind energy, and geothermal energy) show that their contribution will be multiplied by ten, being able to reach 10 or 15 TWyears. This growth in renewable energy will depend above all on its costs, taxes on non-renewable energy and energy policies (Tacuri, 2008; Arauz et al., 2017). The objective of the research is to propose the design of a photovoltaic system from the study of load and demand made of a common dwelling in the canton of Manta, in the province of Manabí.

\section{Materials and Methods}

Different measuring equipment was used to carry out the study of housing load and consumption, in addition the social impact that would be produced by offering clean energy to generate energy and the amount of $\mathrm{CO} 2$ that is emitted to be emitted was calculated the atmosphere when using this type of solution. The PVsyst was used to design the plant (PVSyst, 2004; González et al., 2017).

\section{Results and Discussions}

The production of energy from the sun is based on the physical phenomenon called the photovoltaic effect, which basically consists of converting sunlight into electrical energy by means of semiconductor devices called photovoltaic cells. These cells are made from silicon (one of the most abundant elements, the main component of the sand) with the addition of impurities of certain chemical elements (boron and phosphorus), they are capable of generating a current of 2 to 4 amps, at a voltage from 0.46 to 0.48 Volts, using the sun's light radiation as a source.

The cells are mounted in series on solar panels or modules to achieve adequate voltage. Part of the incident radiation (heat stroke) is lost by reflection (bounces) and another part by transmission (crosses the cell). The rest is able to excite the electrons from one layer to the other creating a current proportional to the incident insolation. An anti-reflective layer increases the effectiveness of the cell (Tacuri, 2008; Suarez et al., 2018).

Pérez, A. V. P., Borges, C. G. R. B., \& Rodríguez, J. A. P. R. (2019). Photovoltaic system proposal for a house. International Journal of Physical Sciences and Engineering, 3(2), 34-43. https://doi.org/10.29332/ijpse.v3n2.330 
Solar energy, together with wind, hydraulic, geothermal and biomass, are considered the energy sources of the future, since unlike conventional resources they are practically inexhaustible, as well as being an ecological option. Photovoltaic systems are a very interesting option, from the technical and economic perspectives, since the region where Ecuador is located has abundant solar radiation throughout the year. Photovoltaic systems (SFV) began to be installed at the beginning of the 80's, of the last century.

In 1995, the worldwide installed capacity in large plants or photovoltaic plants was $600 \mathrm{MWp} ; 16$ years later there was an installed capacity of more than $70 \mathrm{GWp}$ in this type of facilities.

At the end of 2015, the total world power was $227 \mathrm{GWp}$, where the countries with the highest installed capacity are China, Germany, Japan, the United States, and Italy topping the list in that order in Figure 1, it shows global photovoltaic power installed until 2018, in gigawatts (GW), expressed by region (EPIA, 2018).

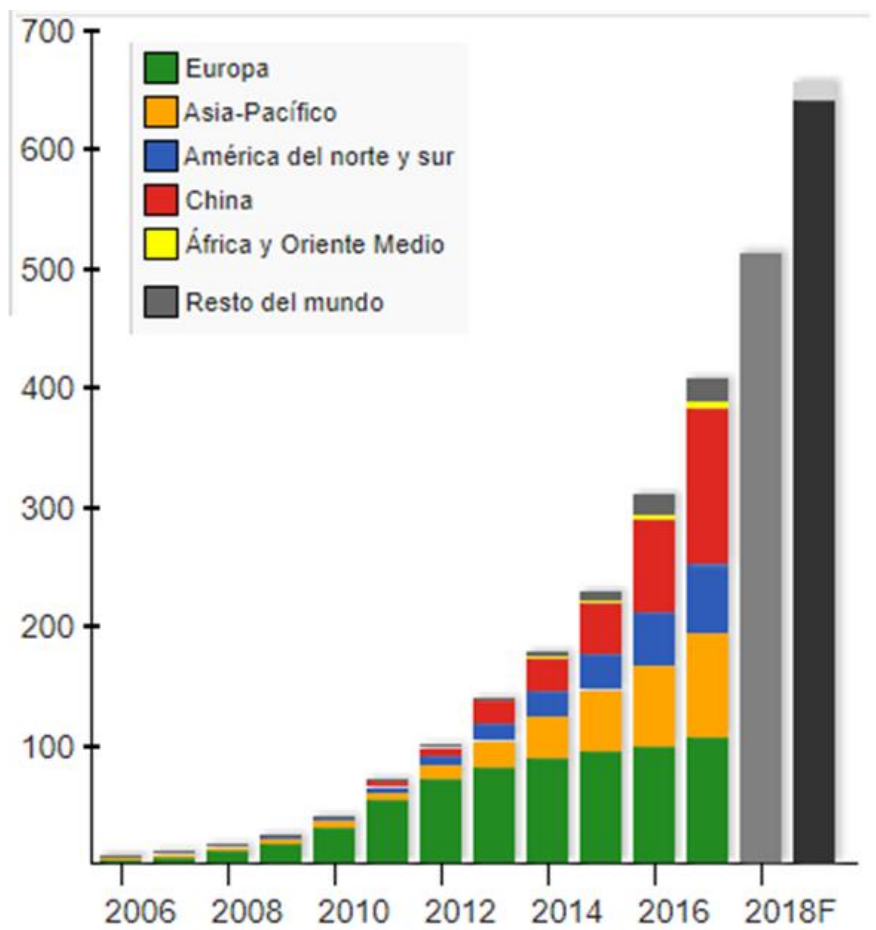

Figure 1. Photovoltaic power installed at 2018

Source: (EPIA, 2018)

In Ecuador, all climatic conditions for the installation of photovoltaic systems are found due to their high levels of solar radiation that affectsmeters2 (Rodríguez \& Vázquez, 2018), several photovoltaic plants have been installed in the four regions of the country for several years, demonstrating that it is valid to install networked systems close to the load, and also isolated systems are included to meet demand in isolated cities and homes (Genial et al., 2018).

To increase the availability of energy, reduce costs, ensure greater quality and reliability of services, you must travel through the use of photovoltaic systems connected to the network and within this modality, prioritize the installation of the systems in places close to the charges

In some cases, due to the limited area available, the roofs of the facilities are used to locate the photovoltaic array, this practice is very common in the world, for example: Bangladesh is the world's largest market for photovoltaic systems for the residential sector, although rapid development is also seen in countries such as Uganda, Kenya, and Tanzania in Africa, Brazil and Guyana in Latin America and China, India and Nepal for Asia (Energy, 2013).

In the country, until 2012, the photovoltaic installations totaled a total of $3 \mathrm{MW}$, in some 9000 low-power photovoltaic systems, almost all remote not connected to the network (CELEC-EP, 2016).

Regarding the energy situation in the residential sector, currently 74478 homes do not receive electric service, which represents $1.9 \%$ of the country's households. Of these, 21194 are located in mountainous areas 
of difficult access, so it is essential to execute a Rural Electrification Program with Renewable Energy Sources (Buitron, 2010).

Future plans establish the electrification of more than 20,000 homes in rural areas within three years, with the corresponding benefit for some 80,000 inhabitants (Vázquez et al., 2018).

This work is aimed at designing a photovoltaic system, capable of satisfying the energy demand of a house and delivering a percentage of the energy generated to the network, as a way to promote the implementation of this technology

\section{Housing characterization}

The photovoltaic system will be assembled on the surface of a house, located in Manta, Canton of the province of Manabí of the Republic of Ecuador. It is located in an ideal site for the design of a photovoltaic system.

The house is composed of a portal, three rooms, a living room, a dining room, a bathroom, and a kitchen. Among the predominant electrical charges are refrigerators, televisions, ventilation equipment, luminaires, and computers, among others. The service is single-phase two-phase at $110 \mathrm{~V}$.

For the design of the plant, a study of the energy consumption of the house was carried out, where it was possible to verify that on average the house makes an expenditure of $17.8 \mathrm{kWh} /$ day and that $40 \%$ of. The same is done during daylight hours, when solar energy is available to be used, which is equivalent to 4.97 $\mathrm{kWh}$. Knowing that the solar potential of the site where the house is located in 4,907 $\mathrm{kWh} / \mathrm{m} 2 \mathrm{day}$ and the normalized productivity as an annual average is 3,552 for polycrystalline silicon, it was possible to calculate that the photovoltaic power required to install in the house is $1,4 \mathrm{kWp}$

The photovoltaic power to be installed was calculated by applying equation 1 (Rodríguez \& Vázquez, 2018).

$$
P f v N i=\frac{C E d h d}{P n}
$$

Where:

PfvNi $\rightarrow$ Photovoltaic power required to be installed (kWp)

CEdhd $\rightarrow$ Daily electricity consumption during daylight hours (kWh day)

$\mathrm{Pn} \rightarrow$ standardized productivity (kWh / kWp day)

Although solar radiation in Ecuador does not It presents significant variations throughout the territory, it greatly influences the expected productivity of the photovoltaic system. But when it comes to photovoltaic systems connected to the grid, intended to generate electricity during its life cycle (25 years), it is required to ensure adequate energy use of the system from the stage of its design. This requirement is achieved to the extent that technology is planned to be installed in the area where there is the best solar potential, thus favoring the economic recovery of the investment in the shortest period of time. For this reason, it is necessary to make an estimate as accurately as possible, taking into account the historical data of the place.

To know the solar potential, several meteorological studies can be used. In the province of Manabí, the information published in the book was used (Rodríguez \& Vázquez, 2018), necessary information to obtain the real data of solar radiation in the place where the house is located, which guarantees a better selection of the photovoltaic system necessary to cover the load of the same. Table 1 shows the average annual radiation values of the Manta canton.

Pérez, A. V. P., Borges, C. G. R. B., \& Rodríguez, J. A. P. R. (2019). Photovoltaic system proposal for a house. International Journal of Physical Sciences and Engineering, 3(2), 34-43. https://doi.org/10.29332/ijpse.v3n2.330 
Table 1

Solar radiation of the canton of Manta

\begin{tabular}{cccccccccccc}
\hline \multicolumn{10}{c}{ Global Radiation $\left(\mathrm{kWh} / \mathrm{m}^{2}\right.$ day $)$} \\
\hline January & February & March & April & May & June & July & August & September & October & November & December \\
\hline 4.80 & 4.45 & 4.91 & 4.76 & 4.70 & 4.77 & 5.14 & 5,93 & 6.38 & 5.56 & 5.81 & 4.75 \\
\hline
\end{tabular}

Source: SIGDS

Design of the photovoltaic system

To perform the simulation of the photovoltaic system connected to the network, the specific conditions of the installation and the electrical production that can be expected from the photovoltaic system among other parameters of interest.

The polycrystalline silicon module was selected because it is suitable for the type of radiation in the Manta canton. In figure 2, the characteristic curve of the module is shown.

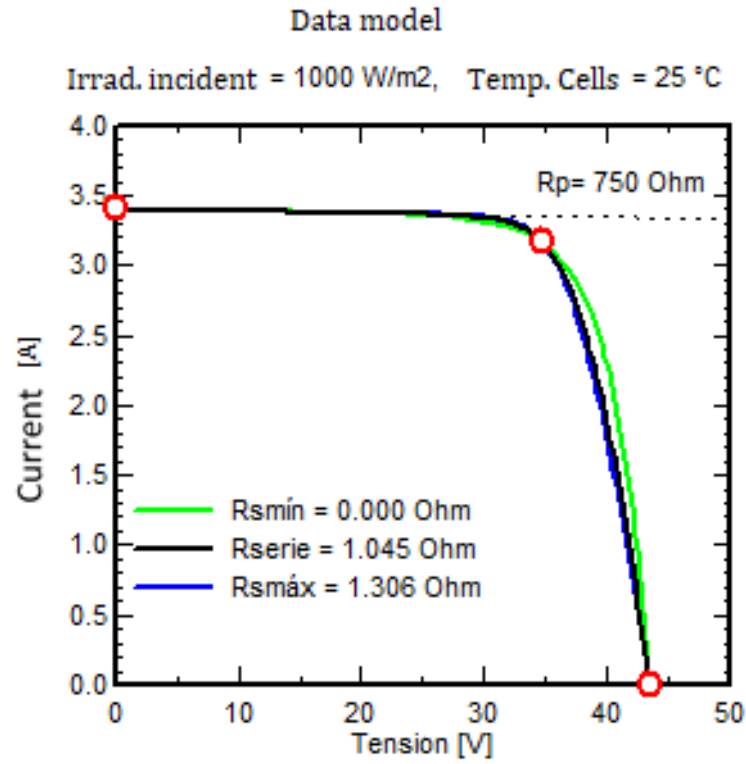

Figure 2. The characteristic curve of the module Source: Simulation obtained from the PVsyst

When considering the geographical location latitude of the Manta canton the inclination angle should be 1 degree, in order to favor the cleaning of the system it was decided to adopt a technical commitment of 10 degrees of inclination, since the deposition of dust in the modules can affect between 40 or $50 \%$ of the energy productivity of the system.

The photovoltaic generator is designed with 14 modules in series with a single chain and located on the roofed surface of the house occupying a space of $13 \mathrm{~m} 2$. With a nominal power of $1240 \mathrm{Wp}$, and a power in operating conditions of $1370 \mathrm{Wp}$ at $50^{\circ} \mathrm{C}$.

A two-phase Sitop Solar T1200 model inverter of $1.2 \mathrm{~kW}$ of power with a minimum voltage of $115 \mathrm{Volt}$, maximum MPP voltage of 250 volt and absolute maximum PV voltage of 350 Volt was selected, in Figure 3 , the curve of investor efficiency. 


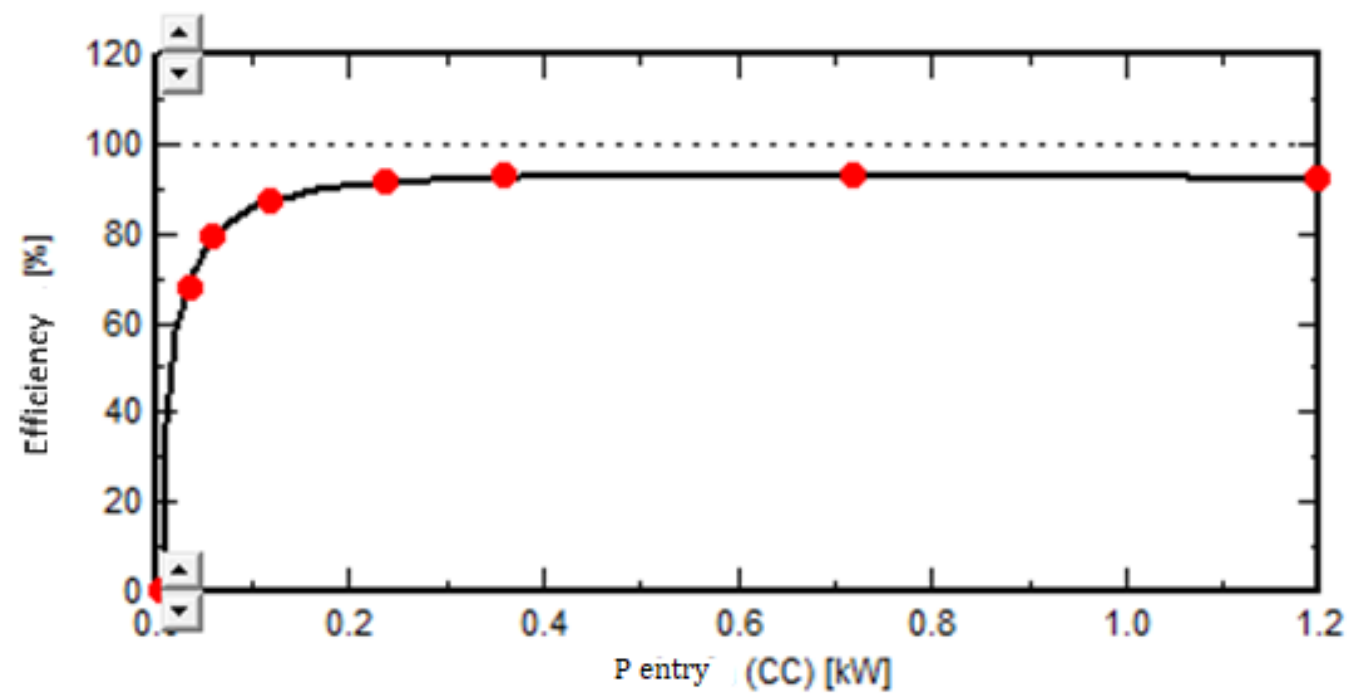

Figure 3. Inverter Efficiency

Source: Simulation obtained from PVsyst

As planned, the scheme of the system would be as shown in Figure 3, the photovoltaic array connected to the inverter that converts direct current into alternating current, this provides power to the load and that is not consumed is incorporated into the electricity grid.

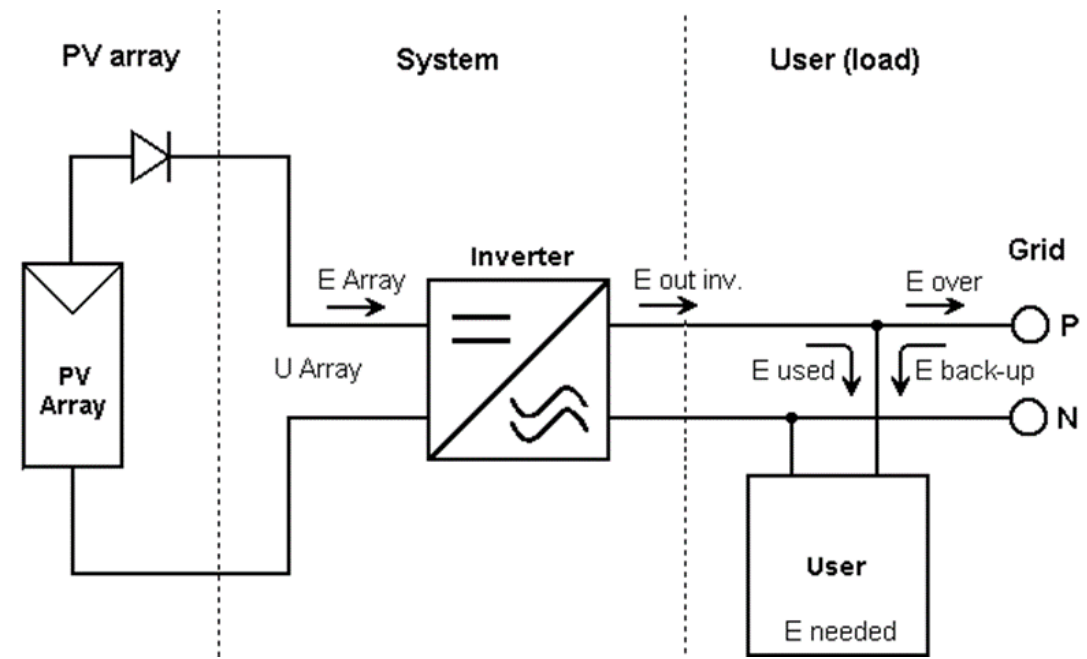

Figure 3. Scheme of the system

Source: Simulation obtained from the PVsyst

The simulation of the system allowed to know the main results obtained that are shown in Table 2, as it can be observed the global radiation, the generated energy and the one that is delivered to the network.

Pérez, A. V. P., Borges, C. G. R. B., \& Rodríguez, J. A. P. R. (2019). Photovoltaic system proposal for a house. International Journal of Physical Sciences and Engineering, 3(2), 34-43. https://doi.org/10.29332/ijpse.v3n2.330 
Table 2

Results obtained

\begin{tabular}{lccc}
\hline $\begin{array}{c}\text { Months of the } \\
\text { year }\end{array}$ & $\begin{array}{c}\text { Global Radiation }(\mathrm{kWh} \\
/ \mathrm{m} 2)\end{array}$ & $\begin{array}{c}\text { Energy generated } \\
(\mathrm{kWh})\end{array}$ & $\begin{array}{c}\text { Energy delivered to the grid } \\
(\mathrm{kWh})\end{array}$ \\
\hline January & 148.9 & 111.2 & 101.9 \\
February & 124.7 & 96.0 & 87.9 \\
March & 152.2 & 120,9 & 111.1 \\
April & 142.7 & 116.8 & 107.3 \\
May & 145.8 & 123.9 & 114.0 \\
June & 143.1 & 123.7 & 114.0 \\
July & 159.2 & 137.6 & 126.9 \\
August & 183.2 & 156,1 & 144.2 \\
September & 191.4 & 156.5 & 144.6 \\
October & 172.5 & 13.7 & 124.1 \\
November & 174.2 & 131.9 & 121.6 \\
December & 147.3 & 110.0 & 100.7 \\
December & 1885.9 & 1519,3 & 1398,3 \\
\hline
\end{tabular}

Source: Simulation obtained from PVsyst

The implementation of photovoltaic technology aims to reduce demand during daylight hours. Figure 4 shows the graphical behavior of the energy generated and delivered to the grid by months, being able to observe that the months of July, August, September, October, and November are the months of greatest generation being above the average total value that it is $116.53 \mathrm{kWh}$, with the month of greatest contribution to the network being September; You can also see that the month of least energy generated delivered to the network is the month of February.

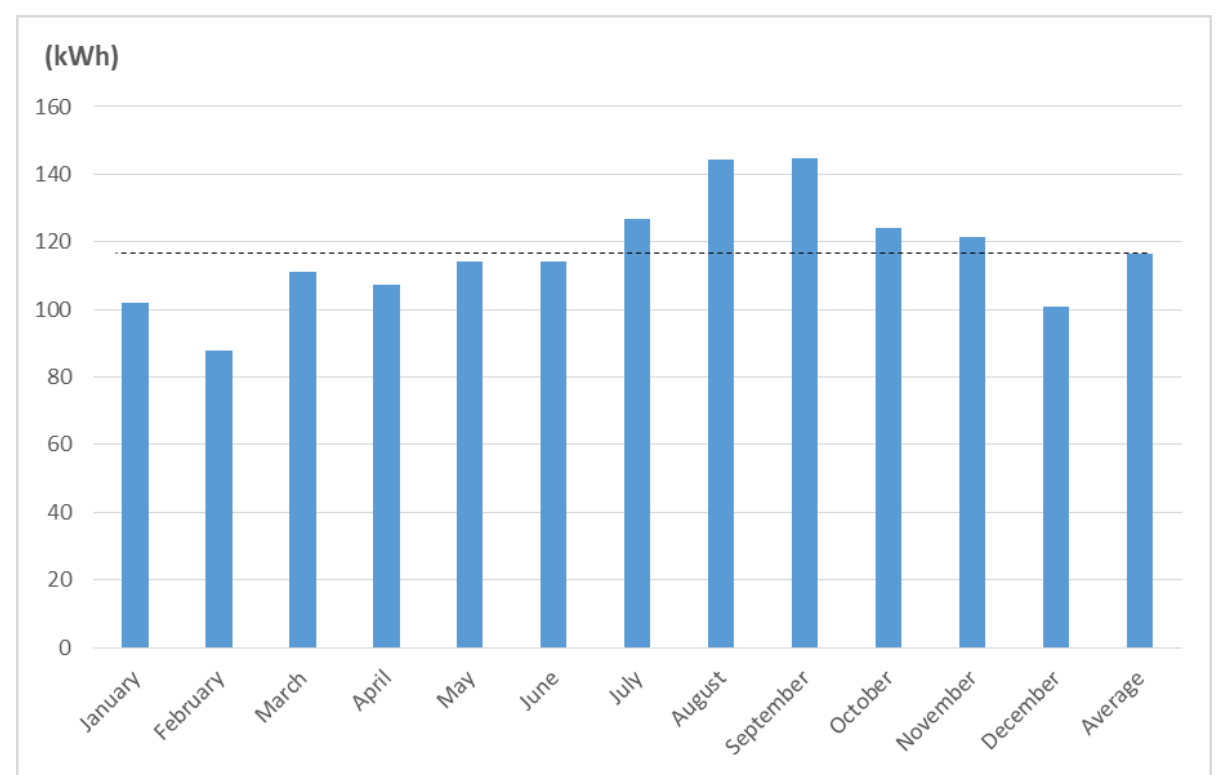

Figure 4. Energy generated delivered to the network Source: Simulation obtained from PVsyst 
Economic and environmental benefits

Economic impact

When analyzing the economic impact of the designed photovoltaic system, it can be deduced that considering an average price of energy paid to the electricity company, equivalent to 0.10 USD, with this you can be saving annually is 139.83 USD; but when considering the real cost of the energy generated and served that can be equivalent to USD 0.23 then the savings for the state can be USD 321.61 .

\section{Environmental impact}

The annual production of the photovoltaic system can potentially avoid the expenditure of $350 \mathrm{~kg}$ of oil per year, equivalent to ceasing to emit 1.26 tons of $\mathrm{CO}_{2}$ into the atmosphere.

\section{Conclusion}

The design and analysis of the results of a photovoltaic power plant connected to the network in the mode of distributed generation for a home constitutes a contribution of academic work for society, allowing through the results the transfer of knowledge in a project that allows to protect natural resources, save economic resources, increase the quality of electricity service and contribute to the reduction of emissions of polluting gases into the atmosphere.

From the scientific point of view, the work constitutes a starting point for the realization of other investigations that allow deepening the subject studied.

\section{Acknowledgments}

To the students that with this investigation will be able to work for the conservation of the natural resources and they will be able to generalize the photovoltaic generation in the country. 


\section{References}

Arauz, W. M. S., Cedeño, G. I., Chávez, S. S., Pérez, A. V., \& Gámez, M. R. (2017). Microgrid with a 3.4 kWp photovoltaic system in the Universidad Técnica de Manabí. International Journal of Physical Sciences and Engineering, 1(2), 11-20. https://doi.org/10.21744/ijpse.v1i2.34

Beltrán-Telles, A., Morera-Hernández, M., López-Monteagudo, F. E., \& Villela-Varela, R. (2017). Prospective of wind and solar photovoltaic energy for electricty production. CienciaUAT, 11(2), 105.

Belvinel, E.-T. G., Loor, G. A., Chilan, J. C. H., \& Gamez, M. R. (2018). Photovoltaic system implementation in baltra and puerto ayora islands. International Journal of Life Sciences, 2(3), 20-27. https://doi.org/10.29332/ijls.v2n3.200

Buitrón, G., \& Carvajal, C. (2010). Biohydrogen production from Tequila vinasses in an anaerobic sequencing batch reactor: effect of initial substrate concentration, temperature and hydraulic retention time. Bioresource Technology, 101(23), 9071-9077. https://doi.org/10.1016/j.biortech.2010.06.127

CELEC-EP. (2016). Photovoltaic solar panels as electrification solutions in isolated communities in the Amazon. https://www.celec.gob.ec/termopichincha/index.php/retos-empresariales/proyectos-degeneracion-no-convencional/energia-fotovoltaica

CIE (2008). Atlas slar of Ecuador for electricity generation purposes. Corporation for Energy Research.

Energetic (2013). Paragachi, the first grid-connected photovoltaic plant in Ecuador, is already underway. Accessed December 2015.. http://www.energetica21.com/

EPIA (2018). Photovoltaic power installed worldwide. https://web.archive.org/web/20140714143734/http://www.epia.org/fileadmin/user_upload/Publicatio ns/EPIA_Global_Market_Outlook_for_Photovoltaics_2014-2018_-_Medium_Res.pdf

González, AED, Arauz, WMS, Gámez, MR, \& Alava, LAC (2017). Photovoltaic energy to face an earthquake. International Journal of Physical Sciences and Engineering, 1(3), 1930. https://doi.org/10.21744/ijpse.v1i3.61

PVSyst. (2004). Tool for the design and technical simulations in photovoltaic systems. www.pvsyst.com

Rodríguez, M., \& Vázquez, A. (2018). Photovoltaic energy in the province of Manabí (EU-U. D. C. University Ed.). Portoviejo, Ecuador: Editorial Technical Unversity of Manabí

Rodríguez, MS, Vázquez, SC, Casas, PM, \& de la Cuerda, RC (2018). Apps in neurorehabilitation. A systematic review of mobile applications. Neurology , 33 (5), 313-326. https://doi.org/10.1016/j.nrl.2015.10.005

Rodríguez-Gámez, M., Vázquez-Pérez, A., Vélez-Quiroz, AM, \& Saltos-Arauz, WM (2018). Improving the quality of energy with photovoltaic systems in rural zones. Scientific journal , (33), 265-274.

Suarez, K. L. C., Carlos, A. G. J., Cuenca, L. A. S., Zambranod, J. A. G., \& Ponce, Ángel A. A. (2018). Demand in abdon calderon parish for possible installation of photovoltaic systems. International Journal of Physical Sciences and Engineering, 2(3), 62-69. https://doi.org/10.29332/ijpse.v2n3.218

Tacuri, J., Romero, E., \& Astudillo, J. (2008). Reality of Ecuadorian youth. Salesian Polytechnic University of Ecuador, Cuenca , 19-23. 


\section{Biography of Authors}

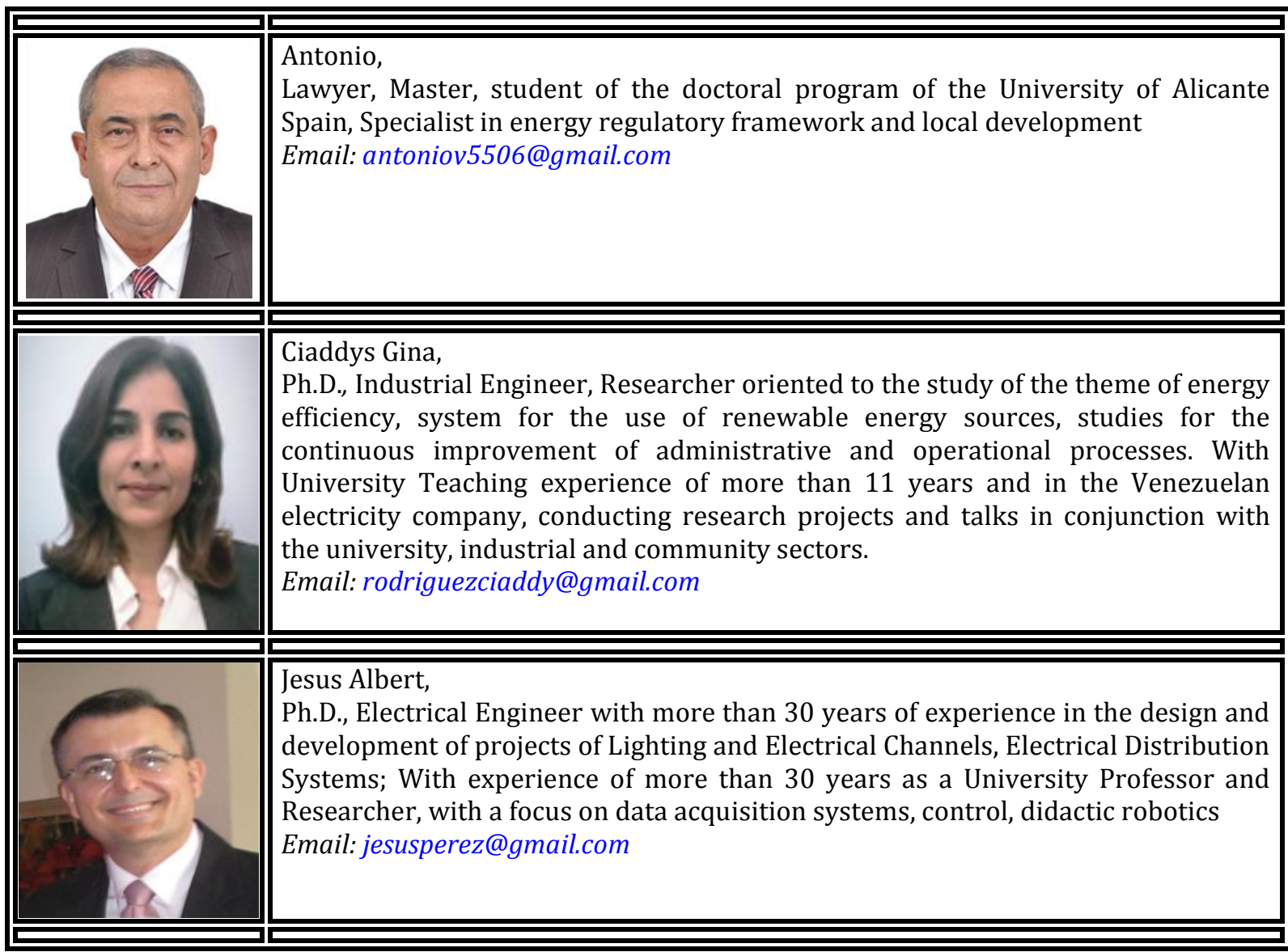

Pérez, A. V. P., Borges, C. G. R. B., \& Rodríguez, J. A. P. R. (2019). Photovoltaic system proposal for a house. International Journal of Physical Sciences and Engineering, 3(2), 34-43. https://doi.org/10.29332/ijpse.v3n2.330 